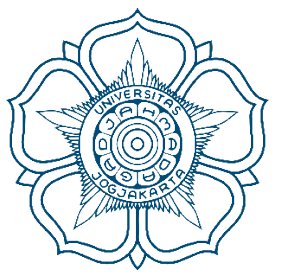

Tittle

: ETHNIC PROFILING AND COUNTER-TERRORISM IN EUROPEAN HUMAN RIGHTS REGIME: A PHILOSOPHICAL LEGAL REVIEW

Author : Mahaarum Kusuma Pertiwi

MIMBAR HUKUM

DOI $\quad$ : http://doi.org/10.22146/jmh.28997

Publisher : Faculty of Law Universitas Gadjah Mada

URL : jurnal.ugm.ac.id/jmh

E Issn : :2443-0994

P Issn : :0852-100x 


\title{
ETHNIC PROFILING AND COUNTER-TERRORISM IN EUROPEAN HUMAN RIGHTS REGIME: A PHILOSOPHICAL LEGAL REVIEW*
}

\author{
Mahaarum Kusuma Pertiwi**
}

Departmen of Constitutional Law, Faculty of Law, Universitas Gadjah Mada, Yogyakarta

Jalan Sosio Yustisia No 1 Bulaksumur, Sleman, D.I. Yogyakarta 55281

\begin{abstract}
This essay will analyze the European Union framework of ethnic profiling in the aim of combating terrorism that will be contrasted to the principle of non-discrimination that is fundamental in the European regime of Human Rights. Research question in this essay is whether the European human rights regime consistently holds the principle of non-discriminatory in justifying the use of ethnic profiling in combating terrorism. Keywords: ethnic profiling, terrorism, non-discrimination, justification.
\end{abstract}

\section{Intisari}

Makalah ini akan membahas mengenai kebijakan profil etnis (ethnic profiling) dalam rangka memerangi terorisme di Uni Eropa yang akan dikontraskan dengan prinsip non-diskriminasi yang juga merupakan hal penting dan mendasar dalam perlindungan Hak Asasi Manusia di Eropa. Permasalahan mendasar yang dikaji dalam studi ini adalah apakah Uni Eropa konsisten dalam memegang prinsip non-diskriminasi ketika membenarkan penggunaan kebijakan profil etnis dalam memberantas terorisme.

Kata Kunci: profil etnis, terorisme, non-diskriminasi, pembenaran.

\section{Pokok Muatan}

A. Research Background 505

B. Research Method 505

C. Research Result and Analysis 505

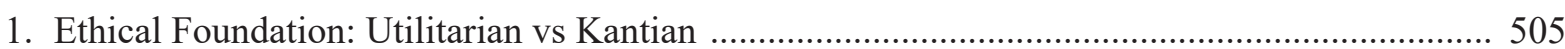

2. Right to Security and Non-Discriminatory Principle ................................................................. 509

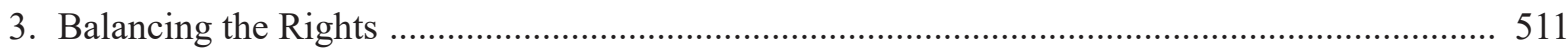

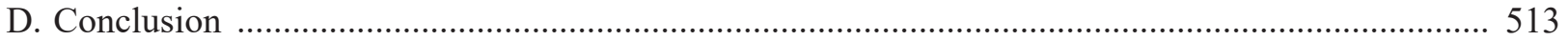

Individual Research 2013

Alamat korespondensi: mahaarum.k@ugm.ac.id. 


\section{A. Research Background}

Ethnic profiling has been used by policemen in various countries around the world. In the United States, for example, it is found out that policemen aggressively targets young black men in poor urban communities. ${ }^{1}$ In the war against terror, ethnic profiling is often being used to protect security. In this sense, deprivations of liberty and privacy are often distributed unevenly along lines of race, class, and religion. ${ }^{2}$ Therefore, the use of ethnic profiling, especially in combating terrorism rises question of its compatibility with the absolute prohibition on discrimination. ${ }^{3}$

Ethnic profiling has become more prominent after the terrorist attack in the United States (2001), Spain (2004), and United Kingdom (2005). However, such policy or discretionary power on labeling people based on their ethnicity could also be viewed as a discrimination towards certain ethnic groups. Although there have been proven cases of terrorism conducted by Muslim, for example, it cannot be used to justify the generalization that all Muslims are terrorist.

There are two regimes that coincide in this regard, counter-terrorism and human rights regime. The first regime dealing with security while the second one dealing with human dignity. When the two conflicting each other, which one should prevail? Is it possible for the two to not conflicting each other but creating harmony instead? The way European regime dealing with this dilemma is the context being drawn in this essay.

Ethnic profiling is commonly practiced in state level policy or law in several European countries. United Kingdom for example has been introducing the power of police to 'stop and search' if they have reasonable ground to suspect any possible crime. The ground in such discretionary power is subjective and as the result, ethnic minorities were being unfairly targeted. ${ }^{4}$ In response, European Union published a guideline to prevent discriminatory ethnic profiling. ${ }^{5}$ Whether the guideline is consistently used in practice will be discussed further in the main part of the essay.

\section{B. Research Method}

This essay is written in a normative legal method which examine the justification or disprove regarding current legal framework of ethnic profiling in conjunction with non-discriminatory clause in the European region. Key sources that being used in this essay are: Normative legal ethics and theories, The European Convention on Human Rights, and case law from the European Court of Human Rights related to ethnic profiling and counter-terrorism.

\section{Research Result and Analysis}

The major academic debate to ground the use of ethnic profiling and the non-discriminatory clause is whether individual rights can and should be sacrificed to give a sense of security for the rest members of the society. In this regard, the essay will contrast the Utilitarian ethics and the Kantian ethics which each gives a moral foundation to justify and disprove the use of ethnic profiling in counterterrorism policy. Further, balancing the right to security and non discriminatory principle will be assessed to measure the justification of ethnic profiling.

\section{Ethical Foundation: Utilitarian vs Kantian}

Utilitarian ethics was popularized by Jeremy Bentham in his book, "An Introduction to the Principles of Morals and Legislation" and later on by John Stuart Mill in his book, "Utilitarianism".

Joscha Legewie, 2016, "Racial Profiling and Use of Force in Police Stops: How Local Events Trigger Periods of Increased Discrimination", American Journal of Sociology, Vol. 122, No. 2, September 2016, pp. 379-424.

Sujit Choudhry and Kent Roach, 2003, "Racial and Ethnic Profiling: Statutory Discretion, Constitutional Remedies, and Democratic Accountability", Osgoode Hall Law Journal, Volume 41, Number 1 (Spring 2003), pp. 1-36.

Helen Duff, 2005, The 'War on Terror' and the Framework of International Law, Cambridge University Press, Cambridge, pp.366-367.

BBC Editor, "Thames Valley Police Stop and Search 'Discrimination' Drop", http://www.bbc.co.uk/news/uk-england-19554435, accessed on 26 Juni 2017.

The guideline was published by the Publication Office of the European Union in 2010 entitled "Towards More Effective Policing. Understanding and Preventing Discriminatory Ethnic Profiling: A Guide". 
In his book, Bentham defines utilitarian by saying, "By the principle of utility is meant that principle which approves or disapproves of every action whatsoever according to the tendency it appears to have to augment or diminish the happiness of the party whose interest is in question: or, what is the same thing in other words to promote or to oppose that happiness. I say of every action whatsoever, and therefore not only of every action of a private individual, but of every measure of government."

By those words, it can be seen that the view of the (classical) Utilitarianism emphasis on the greatest happiness for the greatest number that it should become the ultimate goals of human being. Bentham wrote in his other work, "it is the greatest happiness of the greatest number that is the measure of right and wrong". 7 This means that the happiness of the greatest part of the community could be used to justify the less number of pain gained in the community, even when the pain was suffered by single person in the community. Bentham idea is actually close to the principle of 'voting' in democracy which bring the power of quantity (people) to beat single or less number of ruler having higher authority.

However, Mill who's considered as a Benthamite did not really continue this point of argument. Instead, he developed an opposite idea in explaining Utilitarian. Although Mill also uses the words "the greatest happiness" interchangeable with the Utilitarian ${ }^{8}$ in his book, he also defines who has better authority to claim what best for the society's happiness. Furthermore, Mill differs higher and lower forms of happiness which was not really differed by Bentham.

According to Mill, intellectual and moral pleasures and superior to physical pleasure which he defines as "simple pleasure". He argues that such simple pleasures tend to be preferred by people who have no experience with high art, and are therefore not in a proper position to make a greater decision. He gives an example as: noble or practice philosophy, benefit society more than those who engage in individualist practices for pleasure, which are lower forms of happiness. Mills further explains, although every individual has the personal autonomy, the greatest happiness should be counted as the whole community happiness. Thus, it is not the agent's own greatest happiness that matters but the greatest amount of happiness altogether.'

To illustrate this idea, we can see the real case of Mignonette which was ruled in 1884 by an England Court in the case of the Queen v Dudley and Stephens. ${ }^{10}$ The legal examination of this case will not be discussed in this session. The study will focus on the factual finding of the case instead. On July 1884, an English Yacht registered as English vessel, were cast away in a storm on the high seas 1600 miles from the Cape of Good Hope. Thomas Dudley and Edwin Stephens, the defendants in the case, together with Edmund Brooks, a seaman and Richard Parker, an inexperienced ship boy were forced to leave the yacht and continue to survive on a lifeboat.

Having no water and food supply on the eighteenth day of the survival, the defendants discussed with Brooks on how to survive. The two defendants agreed to sacrifice one of them to save the rest as they dealt between life and death. Brooks refused the idea while the boy Parker was never been consulted. Leaving Brooks, Dudley tried to convince Stephens to kill Parker because he was evidently the sickest and he had no wife nor child that would grieve if he dies. Having heard the arguments, Stephens finally agreed to kill Parker. Together, the two men went to the boy and telling

Bentham, Jeremy, 1789, An Introduction to the Principle of Morals and Legislation, Clarendon Press, Oxford, p. 2.

Bentham, Jeremy, 1776 (second edition enlarged 1823), A Fragment on Government, London Printed for W. Pickering. and E. Wilson, London, p. vi.

Mills, John Stuart, 1863, Utilitarianism, Parker, Son, and Bourn, West Strand, p. 6

Ibid., p.16.

Her Majesty The Queen v. Tom Dudley and Edwin Stephens in the High Court of Justice (Queen's Bench Division) 1884, case number 14 QBD 273 DC. 
him that his time was come, put a knife into his throat and killed him. Hereafter, Dudley, Stephens and also Brooks who rejected the idea to kill anyone to feed the rest, ate Parker's body and drank his blood for the next several days in order to survive. ${ }^{11}$

After days in the sea, the boat was fortunately found by a passing by boat and they were rescued back to the land. The defendants were then carried to the port of Falmouth, and committed for trial at Exeter where the judge by way of a highly unorthodox procedure, hand over the case before a five judge tribunal, presided over by Lord Chief Justice Lord Coleridge, who gave the opinion for the court: guilty as charged. ${ }^{12}$ Although Dudley and Stephens were charged for murder under the law, the trial judge describe them as men of "exemplary courage" while the public sympathetic was mostly given to them. When Dudley traveled from Falmouth to London to meet his wife at Paddington Station, people took their hats off as he passed. Most remarkably, Daniel Parker, Richard Parker's eldest brother, forgave Dudley in open court, and even shook hands with him. ${ }^{13}$

The phenomenon shows that although the current legal system do not justify the sacrificing of one's life to save the others, society might have different opinion in the favor of the Utilitarianism ethic. Justified by this ethic, the limitation of one's rights is actually can and must be done if the rest of the society need it in order to gain the greatest happiness. From this grounded philosophical ethic, I would like to bring a more contextual theory to justify the use of ethnic profiling in counter-terrorism, that is the new paradigm in criminal law emphasizing on the preventive rather than precautionary. To understand this preventive model, a slightly shift from a positivist mindset holding a legal doctrine of
"Nullum crimen sine lege" that being emphasized by Duffy in responding the war on terror ${ }^{14}$ to a more sociological mindset of risk society.

There is no doubt in the factual world that after the terror attack on 9 September 2001 (9/11), life of millions of people never be the same again. Governments of countries throughout the world led by the United States of America declared the war on terror ${ }^{15}$ and start to be skeptical towards certain ethnic groups associated with the terrorist. The skeptical behavior is not only conducted by the government of the state in the name of security, it also provokes the society to be skeptical to difference ethnic groups surrounding them. The exclusion of 'us' against 'them' start to raise the discriminatory attitudes in the name of insecurity.

Long time prior to the attack on $9 / 11$, Ulrich Beck, a German Sociologist has defined such phenomenon as a risk society by describing it as a systematic way of dealing with hazards and insecurities induced and introduced by modernization itself. $^{16}$ In a more contextual definition, British sociologist Anthony Giddens defining risk society as situation where a society increasingly preoccupied with the future (and also with safety), which generates the notion of risk ${ }^{17}$.

Although at first both Beck and Giddens defined risk society in response to the industrial class society that breaking apart as affected by globalization, and transform it into a risk society, this term could also explain terrorism especially when the issue of terrorism and security start to be blown in mass media lead people to openly discuss it and furthermore causing prejudgment in the society towards differences. In discussing governing terrorism after the 9/11, Aradau and Munster conceptualize risk as a dispositif ${ }^{18}$ for governing

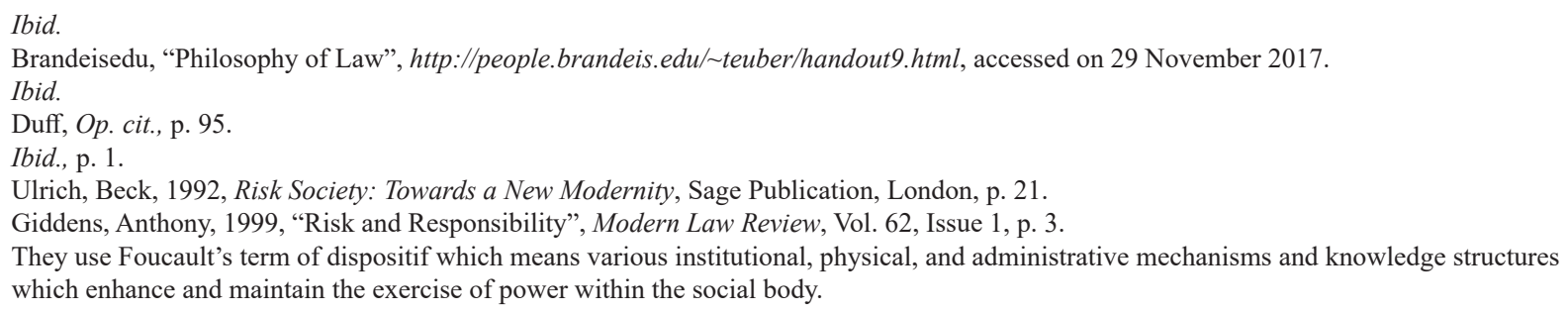


social problem. ${ }^{19}$ They argue furthermore that the dispositif of risk could be seen in the targeting of Muslim communities by counter-terrorism measures or indefinite detention of suspect terrorists in the United Kingdom for example as an elements of precautionary governance through risk. ${ }^{20}$

Counter-terrorism measurement undertaken by the United Kingdom's and other western governments that somehow involving ethnic profiling or discriminating against certain ethnic groups is perceived by Rasmussen as security policy to prevent future threats. ${ }^{21}$ To relate with the utilitarian ethic which has been elaborated above, the government in the United Kingdom and other countries that choose to do ethnic profiling justifying their policy in the name of security. Although individual rights, such as freedom of expression, non-discrimination, and/or freedom of movement might have been violated, as long as greater happiness in the society could be achieved by conducting such manner, it is permissible.

However, in the ethical discourse, such justification of achieving greater happiness is not always agreed by all philosopher. Immanuel Kant has been long time known for his deontological ethic that also known as Kantian ethics.

Kantian ethics is the foundation of human rights in which giving emphasis on individual rights. In contrast to the Utilitarian ethics that justifying an action based on its consequence under the consequentialism school of thought, Kant believe that there is nothing to justify the killing of a person in the name of saving the life of other. Kant rather believes that action should have the form of moral conduct in which he explain in the supreme principle called the categorical imperative. ${ }^{22}$ First, Kant said, "I ought never to act except in such a way that I could also will that my maxim should become a universal law". ${ }^{23}$ The term 'maxim' in this deontological ethic is perceived as a subjective principle or a thought that motivate an individual action, and in the Kantian view, maxim is combined with a certain intention to become moral. And by universal, he means that the same action would be regarded as the same for anyone else anytime anywhere. For example, if one wants to steal from anyone else, then he has to imagine if he is the one being stolen, and that everyone in the world would also steal and being stolen. If he thinks that is not good, then he should think that he should not steal for it would not be good for the person being stolen.

Secondly, Kant challenges the consequentialism's means to end by positioning end as an end. He said, "Act in such a way that you treat humanity, whether in your own person or in the person of any other, never merely as a means to an end, but always at the same time as an end". ${ }^{24}$ Kant uses a clear distinction between black and white and thus no gray area. Individual rights (happiness) should not be manipulated to achieve greater happiness. The goodness or badness of an action is measured by the action itself, not the consequences of the action. For example, in the situation where A asks B who knows where $\mathrm{C}$ is, to tell $\mathrm{A}$ where $\mathrm{C}$ is so that $\mathrm{A}$ can kill $\mathrm{C}$, $\mathrm{B}$ has to tell A what he knows, although it means that $\mathrm{C}$ would be killed. The murder of $\mathrm{C}$ by $\mathrm{A}$ is A's own choice and thus it is not B's responsibility. Furthermore, if the consequentialists say that at the end, C is died because of B's action, Kant will argue that $\mathrm{B}$ can also in the other hand call the police to stop A's plan to kill C.

Third, the kingdom of ends. Where he suggests all people should consider themselves both means and ends by saying, "Therefore, every rational being must so act as if he were through his maxim always a legislating member in the

\footnotetext{
Claudia Aradau and Rens van Munster, 2007, "Governing Terrorism Through Risk: Taking Precautions, (un)Knowing the Future”, European Journal of International Relation, Vol. 13 (1), p. 91. 
universal kingdom of ends." ${ }^{25}$ By this, Kant means that every individual should act so that the action will harmonized with the possible universality of kingdom of ends which gather all ends. All the human being should act in harmonize to build a good kingdom of ends. It also means that no one should act in a bad manner (imperfect duties) so that it would contribute to bad ends.

Kantian ethics gives emphasis on individual rights. Furthermore, it highlighting the importance of individual choices based on his/ her position as a rational agent of his/ her own. Thus in the case of Mignonette that has been described above, Kantian will agree with Lord Chief Justice Lord Coleridge who decided that Dudley and Stephens are guilty and therefore charged with a crime. First, because Parker individual rights were violated, starting from his right to life as the fundamental rights to his right to determine what would happen to his body. Secondly, Parker was never been consulted to the idea of survival and he was involved in the scheme of survival that being designed by Dudley and Stephens. If Parker was consulted by Dudley and Stephens and he agreed to be eaten, Kantian will give no objection to such an action.

The stressing on individual rights makes Kantian ethic the foundation of human rights law. Since human dignity is the essence of human rights, it should not be defeated by other interests. Moreover, although right that being violated is not the right to life, there should not be any justification to violate this right, for example the right to not being discriminated. However, certain rights might be conflicting each other. In the case of counterterrorism to make it contextual, the right of security might conflicting the right to not being discriminated in the case of ethnic profiling. Which one should prevail? Measuring the dilemma between rights could be an option. Therefore, legal framework requires positive measure of the existing legal regulation and jurisprudence to legitimate an action relating to ethnic profiling in combating terrorism. The next part of this essay will elaborate this legal framework with particular context in European human rights regime.

\section{Right to Security and Non-Discriminatory Principle}

When there is two or more rights that conflicting each other, Martha Nussbaum proposes an approach to the dilemma that is by measuring the values on both $\operatorname{sides}^{26}$. In the context of ethnic profiling, there are at least two rights that conflicting each other: the right to security versus prohibition of discrimination.

It should be noticed that in the policy containing ethnic profiling, security is something that is being wanted to be achieved in the future under the term: right of security. If the security in the present that is being struggled for, the government does not need to do profiling, all it needs to do is arrest the person who harm the security in the moment. Thus the debate is about something in the future that no one know what will happen, it is not fair to punish someone for the crime that has not been done. Any punishment should be made before the law (court) and in fact that the individual being profiled is not committing a crime yet does not mean that he will do the crime in the future nor planing or having intention to do so. The worst scenario might be: because he was profiled to do a crime, he is being motivated to do so. Therefore, the policy of ethnic profiling to reduce or minimalize terrorism could also be failed and counter-productive instead.

Under the International Covenant on Civil and Political Rights (ICCPR), the right to security under Article 9 is not subject to non-derogable rights, thus it can be ruled out whenever conflicting to other rights that has non-derogable clause or if certain situation permitting country to derogate the Article under Article 4 of the ICCPR. In the other hand, ICCPR also stating the right to not be held guilty of any crime which did not constitute a 
criminal offence under national or international law in Article 15 as one of its non-derogable articles. By this, it can be contrasted that the right to 'future' security can be derogated, while the right to not being 'discriminated' by law for any crime that has not being committed cannot be derogate.

In the European Convention of Human Rights (ECHR), the right to security is set under Article 5. Similar to the ICCPR, the right to security in the the ECHR also does not constitute non-derogable clause. Article 15 of the ECHR only permitting derogation from Article 2 concerning the right to life in respect of death resulting from lawful sanction; Article 3 concerning prohibition of torture, Article 4 paragraph 1 concerning prohibition of slavery, and Article 7 concerning punishment without law. Therefore, the same legal condition applied in the European regime as the United Nations (ICCPR) regime: ethnic profiling in the name of security can be derogate in certain limited circumstances.

Again, the ICCPR and the ECHR have similar condition to permit derogation. General Comment 29 of the ICCPR stating that any derogation from the ICCPR has to be declared under exceptional and temporary nature. The state must declare itself in an emergency situation before it can declare the derogation. ${ }^{27}$ The ECHR also requires situation of public emergency to declare derogation from its article/s. Therefore, derogation to the right of security could not be used in a long-term normal situation. To sacrifice the right of security in its general meaning only to give an illegal status of ethnic profiling and its future security reason also cannot really be logically accepted.

Ethnic profiling is clearly violating the right to net being discriminated, in particularly based on ethnicity for it targeting certain people based on their ethnicity. Almost all international instrument on human rights prohibit discrimination. From the Universal Declaration of Human Rights in its Article 7; the ICCPR in its Article 4, Article
20, Article 24, and Article 26; the International Convention on the Elimination of All Forms of Racial Discrimination; Convention on the Elimination of All Forms of Discrimination against Women; to ECHR in its Article 14 and its Protocol No. 12, also the Council Directive 2000/43/EC of 29 June 2000 on Implementing the Principle of Equal Treatment between Persons Irrespective of Racial or Ethnic Origin and the Principle of Equal Treatment between Persons that being regulated in the Proposal for a Council Directive of 2 July 2008 on Implementing the Principle of Equal Treatment between Persons Irrespective of Religion or Belief, Disability, Age or Sexual Orientation.

In general, all of the above mentioned articles and conventions prohibit discrimination. Even the ICCPR requires non discrimination in the situation of derogation from its certain derogable articles. ${ }^{28}$ It shows that the United Nations as the biggest states-based international organization agree about the importance of treating all human being in the same manner without any tendency to label people in prejudice in all situation. All European countries which also become the member of the United Nations and moreover, ratify the ICCPR are obliged to comply with the notion of non-discrimination. Thus, although Europe has its own regional legal system, international human rights law applicable under the United Nations shall not be set aside. Even the European Union's legal framework also has the same view towards non-discriminatory principle presented by numbers of its regulation.

To bring the context into European legal framework, it is important to notice the notion set in Article 14 of the ECHR that the non-discriminatory clause is applied to all articles in the ECHR. By this, any discriminatory action by the government in fulfilling, protecting, and respecting every rights set in the ECHR is a violation of Article 14. In practice, never been examined solely in the ECtHR. However, its position as a principle could lead to a

\footnotetext{
27 Human Rights Committee, General Comment 29, States of Emergency (article 4), U.N. Doc. CCPR/C/21/Rev.1/Add.11 (2001)

28 Article 4 (1) of the International Covenant on Civil and Political Rights.
} 
conclusion of breaching other article/s in the ECHR whenever the government give no emphasize on this clause.

However, the situation of the war against terror has trigger several European countries to loosen their commitment towards nondiscriminatory principle. Governments start to launch policy on ethnic profiling and justify it under the right of security. How would they balance the right of security and non-discriminatory principle in regard to ethnic profiling? The next part of this essay will elaborate it.

\section{Balancing the Rights}

Realizing that non-discriminatory clause could in practice conflicting with the counterterrorism policy, the European Parliament published recommendations to the Council on 24 April 2009 regarding the problem of profiling, notably on the basis of ethnicity and race, in counter-terrorism, law enforcement, immigration, customs and border control. ${ }^{29}$ In this document, the European Parliament launched such recommendation after examining that profiling has been growing as a practice in the field of law enforcement and policing in European countries, by targeting specific ethnic, race and religious groups, as well as protesters and travelers.

The recommendation requesting several action to the European countries such as:

a. Law enforcement must always be conducted with due respect for data protection, fundamental rights and the principle of non-discrimination;

b. Current law enforcement and security practices which entail racial, ethnic and behavioral profiling and risk assessment should be subjected to research, analysis and political discussion, with the justification and benefits weighed against the harm from these practices;

c. Existing laws should be examined for the scope they give for profiling, and consideration given to law reform if necessary to ensure that discriminatory impact is avoided; and

d. There is a need to establish a clear definition of legitimate versus illegal uses of sensitive personal data in the security field and to encourage greater cooperation between relevant security agencies in understanding and addressing profiling, and working with relevant communities in this effort.

As a recommendation, and remembering the position of European Parliament as a non-judiciary institution, the document cannot be used to claim that ethnic profiling is illegal and forbidden in Europe. However, it shows that European Union has political tendency to tightening the use of ethnic profiling. Although so, another European Union body, called the EU Fundamental Rights Agency has affirmed that any form of ethnic profiling is likely to be illegal also in terms of international law in which European countries subject to it, because it infringes the guarantees of the International Convention on the Elimination of all Forms of Racial Discrimination. Several domestic court in European countries also ruled that ethnic profiling is illegal, such as Germany Constitutional Court in $2006 .{ }^{30}$

How about the European Court of Human Rights (ECtHR) legal statement on ethnic profiling? The case of Gillan and Quionton vs United Kingdom could explain the position of the court. The case began when in the United Kingdom ethnic profiling can be done under the so called 'stop and search' policy that gives a discretionary power to police to stop any individual that according to subjectivity of the police looks suspicious. ${ }^{31}$ At glance, this policy is normal remembering police duty to secure society. However, the United Kingdom's official data on stop and search practices in England and Wales show significant disparities in the rates at which police stop different ethnic groups. The date reveals that in the period of 1 April 2007 to 31 March 2008,

29 European Parliament Recommendation (2008/2020(INI))

30 European Union Agency for Fundamental Rights, 2010, Towards More Effective Policing, Understanding and Preventing Discriminatory Ethnic Profiling: A Guide, European Union Agency for Fundamental Rights, Belgium, p. 14.

31 Under Section 1 Police and Criminal Evidence Act (PACE) as well as Section 44 of the Terrorism Act 2000. 
there has been a fact that black people were 7.4 times more likely to be stopped and searched than white people. In the same data, it shown that Asian people were 2.3 times more likely to be stopped and searched than white people. ${ }^{32}$

The European Network Against Racism (ENAR) stating that these activities are driven by theories of radicalization which has emerged in response to the phenomenon of so-called homegrown terrorists in the Netherlands, United Kingdom, and other countries. ${ }^{33}$ Radicalization of religion, in particularly Islam has rises certain religious groups that use religion to justify their terror. In response, Police and intelligence services target practitioners of these types of Islam, even when there is no evidence that individual practitioners are involved in terrorism. ${ }^{34}$ In such situation, the case of Gillan and Quintion versus the United Kingdom lodged and ruled in the ECtHR.

Although Gillan and Quinton are not Muslim and they were not being stopped because of their religion, but the same pattern of prejudgment and discriminatory manner involved in the way police stopped them. Thus when the ECtHR ruled the case in favor of the applicants, the judge also ruled generally that it was unlawful for police to use such discretionary power to stop and search people without a solid ground for suspicion.

Gillan and Quinton were stopped by police while they were going to a demonstration outside the annual arms fair at the Excel centre, in London's Docklands, in 9 September 2003. Gillan was stopped and searched by two police officers who told him he was being searched under section 44 of the Terrorism Act 2000 for articles which could be used in connection with terrorism. ${ }^{35}$ The polices stop Gillan because a lot of protesters were about and the police were concerned that they would cause trouble. Gillan was detained for roughly 20 minutes before he was allowed to go. Quinton who was a journalist wearing a photographer's jacket, carrying a small bag and holding a camera standing around the area of the demonstration to film the protests. Although she already shown her press identity card, police still stopped her and asked her to stop filming. The police officer told her that she (the police) was using her powers under sections 44 and 45 of the 2000 Act. Quinton was stopped for several minutes causing her to have felt so intimidated and distressed that she did not feel able to return to the demonstration although it had been her intention to make a documentary or sell footage of it. ${ }^{36}$

The applicants have exhausted domestic remedies without having a satisfactory result so that they lodge the case to the ECtHR by claiming that the United Kingdom through its stop and search policy has breached their right to privacy. The judges in the ECtHR concluded that the use of the coercive powers conferred by the anti-terrorism legislation to require an individual to submit to a detailed search of their person, clothing and personal belongings amounted to a clear interference with the right to respect for private life ${ }^{37}$ stated in Article 8 of the ECHR. The court reasoning that the public nature of the search powers under the United Kingdom Terrorism Act, with the discomfort of having personal information exposed to public view, might even in certain cases compound the seriousness of the interference because of an element of humiliation and embarrassment. ${ }^{38}$

Moreover, the court also notice that the risk of the discriminatory use of the powers against ethnic minorities was a very real consideration and the statistics showed that black and Asian persons

32 Ministry of Justice, 2010, Statistics on Race and the Criminal Justice System 2008/09, A Ministry of Justice Publication under Section 95 of the Criminal Justice Act 1991, p.167.

33 European Network Against Racism, "Ethnic Profiling", http://www.enar-eu.org/IMG/pdf/enar_osji_factsheet_ethnic_profiling_oct09.pdf accessed on 29 November 2013.

Ibid.

Case of Gillan and Quinton v. The United Kingdom (2010) p. 3.

Ibid.

Ibid., p. 36.

Ibid. 
were disproportionately affected. ${ }^{39}$ This reasoning by the court shows that ethnic profiling was in fact being used under the stop and search mechanism and thus it is a discriminatory action. Proven their right of privacy have been breached by the United Kingdom's government, Gillan and Quinton were each granted GBP 500. Afterwards, the United Kingdom agreed to change its policy in stop and search to avoid discriminatory against certain conditions.

\section{Conclusion}

The use of ethnic profiling in combating terrorism shall not be justified. Although rights. philosophical foundation of ethnic profiling can be found in the Utilitarianism perspective, it is mainly against human rights. Kantian ethics will reject the use of ethnic profiling because it discriminates a person based on his natural being. Balancing between the right to security and nondiscriminatory principle is important in this regard. Legally, the European Court of Human Rights has ruled in the favor of the applicant in the case of Gillan and Quinton v. The United Kingdom in the dispute whether the discretionary power of police in conducting stop and search under United Kingdom's Terrorism Act has violated the applicant's human

\section{REFERENCES}

\section{A. Books}

Beck, Ulrich, 1992, Risk Society: Towards a New Modernity, Sage Publications, London.

Bentham, Jeremy, 1776 (Second edition enlarged 1823), A Fragment on Government, London Printed for W. Pickering and E. Wilson, London.

1789, An Introduction to the

Principles of Morals and Legislation, Clarendon Press, Oxford.

Duff, Helen, 2005, The 'War on Terror' and the Framework of International Law, Cambridge University Press, Cambridge.

Ellington, James W, 1993, Immanuel Kant.

Grounding for the Metaphysics of Morals, Hackett Publishing.

European Union Agency for Fundamental Rights, 2010, Towards More Effective Policing. Understanding and Preventing Discriminatory Ethnic Profiling: A Guide, Publication Office of the European Union, European Union Agency for Fundamental Rights, Belgium,

Gregor, Mary (Ed.), 1998, Immanuel Kant. Groundwork of the Metaphysics of Morals,
Cambridge University Press, Cambridge.

Mill, John Stuart,1863, Utilitarianism, Parker, Son, and Bourn, West Strand.

Nussbaum, Martha C., 2000, Women and Human Development: The Capabilities Approach, Cambridge University Press, Cambridge.

Rasmussen, Mikkel Vedby, 2007, The Risk Society at War. Terror, Technology and Strategy in The Twenty-First Century, Cambridge University Press, Cambridge.

\section{B. Journal Articles}

Aradau, Claudia and Rens Van Munster, "Governing Terrorism Through Risk: Taking Precautions, (un)Knowing the Future", European Journal of International Relations, Vol.13 (1), 2007.

Choudhry, Sujit and Kent Roach, "Racial and Ethnic Profiling: Statutory Discretion, Constitutional Remedies, and Democratic Accountability", Osgoode Hall Law Journal, Vol. 41, No. 1, 2003.

Giddens, Anthony, "Risk and Responsibility" Modern Law Review, Vol. 62, Issue 1, 1999.

Legewie, Joscha, "Racial Profiling and Use of Force in Police Stops: How Local Events Trigger 
Periods of Increased Discrimination", American Journal of Sociology, Vol. 122, No.

2, September 2016.

\section{Internet}

ENAR Fact Sheet 40, "Ethnic Profiling", http:// www.enar-eu.org/IMG/pdf/enar_osji factsheet_ethnic_profiling_oct09.pdf, accessed on 29 November 2013.

Brandeis, "Handout", http://people.brandeis. edu/ teuber/handout9.html, accessed on 29 November 2013.

BBC Editor, "Thames Valley Police Stop and Search 'Discrimination' Drop", http://www. bbc. co.uk/news/uk-england-19554435, accessed on 26 November 2017.

\section{Decisions}

Case of Gillan and Quinton v. The United Kingdom in The European Court of Human Rights, Strasbourg, Application Number 4158/05, Decided on 12 January 2010.

Her Majesty The Queen v. Tom Dudley and Edwin Stephens in the High Court of Justice (Queen's Bench Division) 1884, case number 14 QBD 273 DC.

\section{E. Treaties/Statutes}

Council Directive 2000/43/EC of 29 June 2000 on Implementing the Principle of Equal Treatment between Persons Irrespective of Racial or Ethnic Origin.

Convention for the Protection of Human Rights and Fundamental Freedoms, Rome 1950.

Convention on the Elimination of All Forms of Discrimination against Women Adopted and opened for signature, ratification and accession by General Assembly resolution 34/180 of 18 December 1979 entry into force 3 September 1981, in accordance with article 27(1).

European Parliament published recommendations to the Council on 24 April 2009 regarding the problem of profiling, notably on the basis of ethnicity and race, in counter-terrorism, law enforcement, immigration, customs and border control. (2008/2020(INI)).

International Convention on the Elimination of All Forms of Racial Discrimination. Adopted and opened for signature and ratification by General Assembly resolution 2106 (XX) of 21 December 1965 entry into force 4 January 1969, in accordance with Article 19.

International Covenant on Civil and Political Rights (Adopted and opened for signature, ratification and accession by General Assembly resolution 2200A (XXI) of 16 December 1966). 999 UNTS 171.

Protocol No. 12 to the Convention for the Protection of Human Rights and Fundamental Freedoms Rome, 4.XI.2000.

United Kingdom's The Police and Criminal Evidence Act 1984.

United Kingdoms's Terrorism Act 2000.

United Nations Human Rights Committee, General Comment 29, States of Emergency (article 4), U.N. Doc. CCPR/C/21/Rev.1/Add.11 (2001).

United Nations Universal Declaration of Human Rights 1948. 